\title{
Effects of soybean meal substitution with isolated soya protein in pre-starter diet on immune system and performance of broiler chickens
}

\author{
A. Nabizadeh ${ }^{1}$ \\ Islamic Azad University, Bojnourd Branch, Department of Animal Science \\ 94176-97796 Bojnourd, Iran
}

KEY WORDS: broilers, pre-starter diet, isolated soya protein, immune response, performance

Received: 24 September 2017

Revised: $\quad 2$ June 2018

Accepted: 10 August 2018

${ }^{1}$ Corresponding author:

e-mail: alinabizadehalinabizadeh@yahoo.com

\begin{abstract}
The aim of the study was to evaluate the effectiveness of soybean meal (SBM) substitution with isolated soya protein (ISP) in pre-starter diet on immune system and performance of broiler chickens. After sex identification, 200 male Ross 308 broiler chicks were randomly allotted to 4 treatment groups with 5 replicates, 10 birds in each, and fed for 35 days. Experimental treatments including 4 substitution levels of SBM with ISP $(0,10,20$ and $30 \%)$ were fed from 1 to 7 day of age. Then all birds were fed common grower (days 7-24) and finisher (days 24-35) commercial diets. Dietary ISP inclusion improved $(P<0.05)$ body weight gain and feed conversion ratio during days 1-7 and 1-24 of age. Dietary ISP supplementation increased $(P<0.05)$ European Production Efficiency Factor and protein efficiency ratio throughout the experiment. Dietary ISP inclusion did not have an effect on relative weight of immune organs at days 3 and 7 of age. Dietary ISP inclusion linearly increased total anti-sheep red blood cells (anti-SRBC) $(P=0.017)$, immunoglobulin $(\mathrm{lg}) \mathrm{G}(P=0.021)$ and $\operatorname{lgM}(P=0.003)$ at 35 day of age. So, the inclusion of ISP ( 20 or $30 \%$ substitution of the SBM) in the pre-starter diet may improve immune response and performance of broiler chickens.
\end{abstract}

\section{Introduction}

Digestive system, mainly its physiology and morphology, is not fully developed in newly hatched broiler chicks (Jin et al., 1998). Intestinal villus height rapidly increases during the first week of life (Wijtten et al., 2011), and pancreatic and biliary secretion may be insufficient in the first week after hatch, especially to digest proteins (Noy and Sklan, 1997). Due to this, feed is not completely digested in the pre-starter period. On the other hand, appropriate nutrient absorption from digestive tract is essential for maturity and development of some body systems (e.g., immune system) and thermoregulation. In addition, due to positive correlation between seven-day live weight and final weight of broiler chickens (Willemsen et al., 2008), feeding animals highly digestible ingredients can improve an economic efficiency (Sklan and Noy, 2003). Soybean meal (SBM) is commonly used as the main dietary source of protein for broiler chicks; however non-starch polysaccharides (NSPs) constitute a significant part of SBM. Total NSPs and soluble NSPs contents in SBM equal 192 and $27 \mathrm{mg} / \mathrm{g}$, respectively (Irish and Balnave, 1993). As digesta viscosity increases, soluble NSPs prevent the enzymatic digestion and reduce protein and amino acid digestibilities (Siddhuraju and Becker, 2005). The soluble NSPs due to anti-nutritive activities may affect gut physiology, microflora and health of birds (Choct, 
2015). Isolated soya protein (ISP) has higher nutritional value than SBM which is characterized by a high protein content (90\%), low anti trypsin (less than $1 \mathrm{mg}$ per $\mathrm{kg}$ ), zero or negligible oligosaccharides and antigenic factors contents (Peisker, 2001). The non-protein components of ISP such as NSPs are removed during the protein isolation process (Grieshop and Fahey, 2000). Anti-nutritional contents of SBM may affect small intestine characteristics and decrease digestive enzymes activities, especially at starter phase (Saki et al., 2012). ISP that is characterized by zero or negligible oligosaccharides and antigenic factors content may be an appropriate source of protein in order to improve the immune system and performance of broiler chickens. Therefore, the purpose of this study was to evaluate the effects of SBM substitution with ISP in pre-starter diet on immune system and performance of broiler chickens.

\section{Material and methods}

The experimental protocol was approved by the Animal Welfare Committee, at the Islamic Azad University of Bojnourd (Iran).

\section{Birds, housing and diets}

In total, 200 1-day-old Ross 308 broiler chicks (average body weight $=44 \mathrm{~g}$ ) were randomly assigned to 4 treatments of 5 replicates with 10 birds in each replicate. Replicate groups of chicks were housed in independent pens $(100 \times 100 \times 70 \mathrm{~cm})$, each equipped with two nipple drinkers and a hanging plastic feeder for manual feed distribution. The pens had a concrete floor and were bedded by clean wood shavings litter. All chicks had unrestricted access to feed and water throughout the experiment. All chicks were exposed to $23: 1$ light:dark cycle. Temperature was initially set at $32{ }^{\circ} \mathrm{C}$ on day 1 and then it was decreased by $0.5^{\circ} \mathrm{C}$ per day to reach $21^{\circ} \mathrm{C}$ on day 23 and kept constant thereafter. To protect birds against Newcastle Disease (ND) and Infectious Bursal Disease (IBD) all birds were vaccinated as scheduled followed by the veterinary official.

Treatments were at four substitution levels of SBM with ISP $(0,10,20$ and $30 \%)$. The ISP used in this study was a commercial product (Shangdong Yuxin Bio-Tech Co., Qing-dao, China) which contained: \%: crude protein 90 , moisture 5.2 , fat 0.5 , NSP 1.2 and ash 3.1. The 4 treatment diets were fed in a completely randomized design from day 1 to 7 of age. Then all birds were fed a common grower (days 7-24) and finisher (days 24-35) commercial diets based on Ross Broiler Nutrition Specification
Table 1. Ingredients of the pre-starter diets fed from 1 to 7 day of age ${ }^{1}$

\begin{tabular}{lllll}
\hline Ingredient, \% & \multicolumn{4}{c}{ Soybean } \\
\cline { 2 - 5 } & 0 & 10 & 20 & 30 \\
\hline Maize grain (8.5\%) & 56.64 & 56.64 & 56.64 & 56.64 \\
Soybean meal (46\%) & 27.81 & 25.04 & 22.25 & 19.47 \\
ISP $(90 \%)$ & 0 & 1.46 & 2.91 & 4.37 \\
Maize gluten meal (60\%) & 8.91 & 8.41 & 7.94 & 7.44 \\
Casein (80\%) & 1 & 1 & 1 & 1 \\
Wheat bran (15\%) & 1 & 2.58 & 4.17 & 5.79 \\
Soybean oil & 0.18 & 0.36 & 0.55 & 0.47 \\
Calcium carbonate & 1.39 & 1.40 & 1.41 & 1.42 \\
Dicalcium phosphate & 1.70 & 1.70 & 1.70 & 1.69 \\
Sodium chloride & 0.39 & 0.39 & 0.39 & 0.38 \\
Lysine-HCl & 0.3 & 0.3 & 0.3 & 0.3 \\
DL-methionine & 0.18 & 0.21 & 0.22 & 0.23 \\
Threonine & - & 0.01 & 0.02 & 0.03 \\
Vitamin + mineral premix & 0.5 & 0.5 & 0.5 & 0.5
\end{tabular}

${ }^{1}$ similar commercial maize-soya grower and finisher diets were fed to all birds from days 7-24 and 24-35 of age, respectively; ${ }^{2}$ ISP = isolated soy protein; ${ }^{3}$ each $\mathrm{kg}$ of diet contained: IU: vit. A 9000, vit. D3 2000, vit. $E 18$; mg: vit. $K_{3} 2$, vit. $B_{1} 1.8$, vit. $B_{2} 6.6$, vit. $B_{3} 10$, vit. $B_{5} 30$, vit. $B_{6} 3$, vit. $B_{9} 1$, vit. $B_{12} 0.015$, vit. $H_{2} 0.1$, choline choloride 500; Mn 100, Fe 50, Zn 100, Cu 10, Mg 3.5, Se 0.2

(Aviagen, 2014) in a mash form. The ingredients and chemical composition of the diets are shown in Tables 1 and 2, respectively.

Table 2. Chemical composition of the pre-starter diets fed from days 1 to 7 of age ${ }^{1}$

\begin{tabular}{lrrrr}
\hline \multirow{2}{*}{ Nutrient, \% } & \multicolumn{5}{l}{ Soybean meal substitution, \% } \\
\cline { 2 - 5 } & \multicolumn{1}{c}{10} & \multicolumn{1}{l}{20} & \multicolumn{1}{l}{30} \\
\hline ME, kcal/kg & 3000 & 3000 & 3000 & 3000 \\
Crude protein & 22.87 & 22.96 & 22.85 & 22.97 \\
Lysine & 1.29 & 1.29 & 1.29 & 1.29 \\
Met + Cys & 0.95 & 0.95 & 0.95 & 0.95 \\
Threonine & 0.90 & 0.90 & 0.90 & 0.90 \\
Ca & 0.96 & 0.96 & 0.96 & 0.96 \\
Available P & 0.48 & 0.48 & 0.48 & 0.48 \\
Na & 0.17 & 0.17 & 0.17 & 0.17 \\
\hline
\end{tabular}

ME - metabolizable energy; ${ }^{1}$ similar commercial maize-soya grower and finisher diets were fed to all birds from days 7-24 and 24-35 of age, respectively; ${ }^{2}$ analysed values

\section{Performance measurements}

Records for live body weight and feed intake were obtained on days 3, 7, 24 and 35. Feed intake (FI) was determined from the difference between supplied and residual feed in each pen. Mortality was recorded by pen number, date and weight of carcass and was added to the total pen live body weight for calculation of feed conversion ratio (FCR). The FCR was calculated by dividing total FI by body weight gain (BWG) of birds for each pen 
during every period. The following formulas were used to calculate European Production Efficiency Factor (EPEF) and protein efficiency ratio (PER):

$$
\begin{gathered}
\mathrm{EPEF}=\frac{\text { survival } \text { rate }(\%) \times \text { live weight }(\mathrm{kg})}{\mathrm{FCR} \times \text { age }(\text { day })} \times 100 \\
\mathrm{PER}=\frac{\text { weight gain }(\mathrm{g})}{\text { protein intake }(\mathrm{g})}
\end{gathered}
$$

\section{Immune organ weights}

At 3 and 7 day of life, two chickens from each replicate were randomly selected, weighed and killed by cervical dislocation. Spleen, thymus and bursa of Fabricius were removed, weighed and expressed as:

$$
\frac{\text { organ weight }}{\text { body weight }} \times 100
$$

\section{Humoral immune response to SRBC}

Non-pathogenic antigen, sheep red blood cell (SRBC), was used to monitor the humoral immune response in broiler chickens. Total anti-SRBC antibody titer was measured by a haemagglutination test. Two chicks in each replicate were intramuscularly injected with $1 \mathrm{ml}$ of a $15 \%$ suspension of SRBC at 21 and 28 day of age. Antiserums were collected 7 days after the immune challenge at 28 and 35 day of age. The serum from each sample was collected, inactivated by heating at $56^{\circ} \mathrm{C}$ for $30 \mathrm{~min}$ and then analysed for total anti-SRBC, mercaptoethanol-resistant (MER) and mercaptoethanol-sensitive (MES) antibody titers. MER and MES titers are presumably immunoglobulin (Ig) G and IgM, respectively. The difference between the total and the $\mathrm{IgG}$ response was considered to be equal to the IgM antibody level (Cheema et al., 2003).

\section{Statistical analysis}

Data were analysed in a completely randomized design, using the general linear models procedure of SAS software version 9.2 (SAS Institute Inc., Cary, NC, USA). Means were compared by Duncan's multiple-range test. A difference with equal or less than $5 \%(P \leq 0.05)$ probability was considered significant.

\section{Results and discussion}

\section{Performance measurements}

The effects of SBM substitution with ISP in pre-starter diet on broiler chickens performance are shown in Tables 3 and 4. The inclusion of ISP in the pre-starter diet did not have an effect $(P>0.05)$ on FI, BWG, FCR, PER and EPEF during 1-3 days of age (data not shown). Feeding pre-starter diet having 20 or $30 \%$ SBM substituted with ISP increased $(P<0.05)$ FI during $1-24$ days of age. The dietary inclusion of ISP increased $(P<0.05)$ BWG during 1-7, 1-24 days of age. Replacement of SBM with ISP at 20 or $30 \%$ levels numerically increased final body weight by about $2.7 \%$ compared with broiler chickens fed on the basal diet based on SBM only. The better $(P<0.05)$ FCR in the periods $1-7$, 1-24 days of age was obtained when birds were fed pre-starter diet containing different levels of ISP. Statistical analysis of the obtained data revealed that inclusion of ISP instead of SBM at 10\% significantly reduced FCR in comparison to birds fed control diet in the periods 1-7 and 1-24 days of age; the $30 \%$ substitution caused further FCR decrease in comparison to $10 \%$ substitution, but neither 10 nor $30 \%$ differ from $20 \%$ substitution. Ebling et al. (2015) reported that diets with 6\% ISP increased the coefficients of total tract apparent retention of dry

\begin{tabular}{|c|c|c|c|c|c|c|c|c|c|}
\hline \multirow{3}{*}{ Indices } & \multicolumn{3}{|c|}{ FI, g/chick } & \multicolumn{3}{|c|}{ BWG, g/chick } & \multicolumn{3}{|c|}{ FCR, g/g } \\
\hline & \multicolumn{9}{|c|}{ days } \\
\hline & $1-7$ & $1-24$ & $1-35$ & $1-7$ & $1-24$ & $1-35$ & $1-7$ & $1-24$ & $1-35$ \\
\hline \multicolumn{10}{|c|}{ Substitution $1, \%$} \\
\hline 0 & 164 & $1297^{b}$ & $2689^{a b}$ & $105^{c}$ & $904^{c}$ & 1802 & $1.312^{\mathrm{a}}$ & $1.435^{\mathrm{a}}$ & 1.492 \\
\hline 10 & 161 & $1292^{b}$ & $2657^{b}$ & $108^{b}$ & $928^{b}$ & 1820 & $1.247^{\mathrm{b}}$ & $1.392^{b}$ & 1.460 \\
\hline 20 & 161 & $1315^{a}$ & $2667^{a b}$ & $108^{b}$ & $954^{a}$ & 1847 & $1.224^{\mathrm{bc}}$ & $1.378^{\mathrm{bc}}$ & 1.444 \\
\hline 30 & 162 & $1318^{a}$ & $2692^{\mathrm{a}}$ & $111^{a}$ & $960^{a}$ & 1851 & $1.180^{\circ}$ & $1.333^{c}$ & 1.554 \\
\hline SEM $^{2}$ & 4.98 & 30.54 & 51.35 & 3.69 & 49.90 & 22.18 & 0.0002 & 0.0002 & 0.0002 \\
\hline$P$-value & 0.173 & $<.0001$ & $<.0001$ & 0.001 & $<.0001$ & 0.079 & 0.0001 & $<.0001$ & 0.076 \\
\hline \multicolumn{10}{|c|}{ Orthogonal polynomials } \\
\hline linear & 0.191 & $<.0001$ & $<.0001$ & 0.0001 & $<.0001$ & 0.585 & $<.0001$ & $<.0001$ & 0.688 \\
\hline quadratic & 0.070 & 0.102 & $<.0001$ & 0.768 & 0.10 & 0.039 & 0.074 & 0.003 & 0.013 \\
\hline
\end{tabular}

Table 3. Effect of pre-starter diet containing different levels of soybean meal substitution with isolated soya protein on broiler chicken's performance: feed intake (FI), body weight gain (BWG) and feed conversion ratio (FCR)

${ }^{1}$ soybean meal substitution with isolated soya protein in pre-starter diet; ${ }^{2}$ SEM - standard error of mean; ${ }^{\text {ab }}$ - means with different superscript within the column are significantly different at $P \leq 0.05$ 
Table 4. Effect of pre-starter diet containing different levels of soybean meal substitution with isolated soya protein on protein efficiency ratio (PER) and European Production Efficiency Factor (EPEF) in broiler chickens

\begin{tabular}{|c|c|c|c|c|c|c|}
\hline \multirow{3}{*}{ Indices } & \multicolumn{3}{|l|}{ PER } & \multicolumn{3}{|l|}{ EPEF } \\
\hline & \multicolumn{6}{|c|}{ days } \\
\hline & $1-7$ & $1-24$ & $1-35$ & $1-7$ & $1-24$ & $1-35$ \\
\hline \multicolumn{7}{|c|}{ Substitution $1, \%$} \\
\hline 0 & $2.78^{b}$ & $3.17^{c}$ & $3.11^{b}$ & 277 & $262^{\circ}$ & $336^{c}$ \\
\hline 10 & $2.90^{\mathrm{a}}$ & $3.27^{\mathrm{b}}$ & $3.23^{a}$ & 280 & $278^{b}$ & $352^{b}$ \\
\hline 20 & $2.93^{\mathrm{a}}$ & $3.30^{\mathrm{ab}}$ & $3.22^{\mathrm{a}}$ & 281 & $288^{a}$ & $357^{a}$ \\
\hline 30 & $2.97^{\mathrm{a}}$ & $3.31^{\mathrm{a}}$ & $3.24^{\mathrm{a}}$ & 285 & $291^{a}$ & $359^{a}$ \\
\hline $\mathrm{SEM}^{2}$ & 0.003 & 0.001 & 0.001 & 7.18 & 8.12 & 12.77 \\
\hline$P$-value & 0.0001 & $<.0001$ & $<.0001$ & 0.567 & $<.0001$ & 0.0004 \\
\hline \multicolumn{7}{|c|}{ Orthogonal polynomials } \\
\hline linear & $<.0001$ & $<.0001$ & $<.0001$ & $<.0001$ & $<.0001$ & 0.0003 \\
\hline quadratic & 0.090 & 0.003 & $<.0001$ & 0.272 & 0.005 & 0.004 \\
\hline
\end{tabular}

${ }^{1}$ soybean meal substitution with isolated soya protein in pre-starter diet; ${ }^{2}$ SEM - standard error of mean; ${ }^{\text {abc }}$ - means with different superscript within the column are significantly different at $P \leq 0.05$

matter (DM) and gross energy (GE), but decreased FI, which negatively affected broiler performance. Longo et al. (2005) also reported that diets with 5.35\% ISP decreased FI, but observed similar average daily gain (ADG) and FCR. In the present study, feeding pre-starter diet containing ISP improved broiler chickens performance. Similarly, van der Eijk (2015) showed that ISP inclusion improved $(P<0.05)$ feed utilization. It has been reported that $5 \%$ processed soya protein improved BWG and feed efficiency of 7 dayold chickens, whereas improved FCR was reported for young turkeys fed diet containing ISP (Jankowski et al., 2009). In this study ISP inclusion in pre-starter diet improved BWG and FCR in broiler chickens. The SBM is known to contain anti-nutritional compounds, such as soya antigens and lectins ( $\mathrm{Li}$ et al., 2003) and trypsin inhibitors which have been shown to be detrimental to bird's performance (Friedman et al., 1991). Such anti-nutritional factors present in SBM, may affect small intestine characteristics and decrease digestive enzymes activities and consequently reduce broiler performance (Saki et al., 2012). These factors not only reduce the nutritional value of SBM but also reduce the utilization of nutrients from other ingredients. Processed soya products including soya protein concentrate (SPC) and ISP contain lower amount of oligosaccharides and antigenic substances. Therefore, these products have higher nutritive values than SBM (Peisker, 2001).

\section{Immune system}

Dietary ISP inclusion did not have an effect $(P>0.05)$ on relative weight of immune organs at 3 and 7 day of age (data not shown). The lack of significant effect of ISP inclusion on the relative immune organ weight could be due to the short duration (only 7 days) of pre-starter diet feeding period and too fast introduction of the common grower (days 7-24) and finisher (days 24-35) commercial diets. SBM substitution with ISP in pre-starter diet did not have an effect $(P>0.05)$ on the total anti-SRBC titer and IgG titers of broiler chickens at 28 and 35 day of age (Table 5). The IgM titer did not differ between groups at 28 day of life but it was significantly higher in groups fed pre-starter diet containing 20 or $30 \%$ SBM substitution with ISP at 35 days of age $(P=0.003)$. For all parameters (total anti-SRBC, IgG and $\operatorname{IgM})$ there was stated the linear increase $(P=0.017, P=0.021$ and $P=0.0003$, respectively $)$ at 35 day of age (Table 5). Based on gene expression patterns in jejunal tissue, dietary protein source influences the expression of genes responsible for mucin secretion, amino acid transport and immune functionality in an age dependent manner (Cowieson et al., 2016). Soya, as a plant source of dietary proteins for animal, contains a range of phytochemicals, such as isoflavones: genistein, daidzein and glycitein. Isoflavones content in ISP was $91.05 \mathrm{mg}$ per $100 \mathrm{~g}$ as reported by Bhagwat et al. (2017). Inhibition of pathogens (phytoalexin activity) and molecular signal in symbiotic interaction (in mycorrhizia and rhizobia) are areas where isoflavones are essential (Lozovaya et al., 2007; Mierziak et al., 2014). Soya protein can affect immune response and act as antitumor factor (Ford et al., 2001). Isoflavones influence the signal transduction process of macrophages and

Table 5. Effect of pre-starter diet containing different levels of soybean meal substitution with isolated soya protein on immune response in broiler chickens

\begin{tabular}{|c|c|c|c|c|c|c|}
\hline \multirow[t]{3}{*}{ Indices } & \multicolumn{2}{|c|}{$\begin{array}{l}\text { Total anti-SRBC } 1 \\
\mathrm{mg} / \mathrm{dl}\end{array}$} & \multicolumn{2}{|l|}{$\begin{array}{l}\mathrm{lgG}^{2} \\
\mathrm{mg} / \mathrm{dl}\end{array}$} & \multicolumn{2}{|l|}{$\begin{array}{l}\mathrm{lgM}^{3} \\
\mathrm{mg} / \mathrm{dl}\end{array}$} \\
\hline & \multicolumn{6}{|c|}{ day } \\
\hline & 28 & 35 & 28 & 35 & 28 & 35 \\
\hline \multicolumn{7}{|c|}{ Substitution 4 \% } \\
\hline 0 & 367.8 & 555.1 & 309.2 & 430.8 & 58.6 & $124.3^{b}$ \\
\hline 10 & 370.5 & 562.0 & 307.7 & 437.2 & 62.8 & $124.8^{b}$ \\
\hline 20 & 370.8 & 571.6 & 310.2 & 442.6 & 60.6 & $129.0^{\mathrm{a}}$ \\
\hline 30 & 374.8 & 578.2 & 312.0 & 446.8 & 62.8 & $131.4^{a}$ \\
\hline SEM $^{5}$ & 17.46 & 38.95 & 18.62 & 33.100 & 8.62 & 5.74 \\
\hline$P$-value & 0.585 & 0.099 & 0.423 & 0.108 & 0.473 & 0.003 \\
\hline \multicolumn{7}{|c|}{ Orthogonal polynomials } \\
\hline linear & 0.479 & 0.017 & 0.229 & 0.021 & 0.224 & 0.0003 \\
\hline quadratic & 0.345 & 0.965 & 0.0001 & 0.733 & 0.404 & 0.675 \\
\hline
\end{tabular}

${ }^{1}$ total anti-SRBC - sheep red blood cells; ${ }^{2} \mathrm{lgG}$ - immunoglobulin $\mathrm{G} ;{ }^{3} \mathrm{IgM}$ - immunoglobulin $\mathrm{M} ;{ }^{4}$ soybean meal substitution with isolated soya protein in pre-starter diet; ${ }^{5} \mathrm{SEM}$ - standard error of mean; ab - means with different superscript within the column are significantly different at $P \leq 0.05$ 
other phagocytic cells and the activity of cytotoxic $\mathrm{T}$ lymphocytes, thus affect both innate and adaptive immunity (Ford et al., 2001).

\section{Conclusions}

Soybean meal (SBM) substitution with isolated soya protein (ISP) in the pre-starter diet can improve the overall growth performance and immune response of broiler chickens. The substitution of 20 or $30 \%$ of SBM with ISP could be suggested as beneficial for the bird health.

\section{Acknowledgements}

The author wish to thank the Vice President in Research and Technology, at the Azad university of Bojnourd for their financial and technical supports.

\section{References}

Aviagen, 2014. Ross 308 Broiler: nutrition specifications, http://aviagen. com.

Bhagwat S., Haytowitz D.B., Wasswa-Kintu S., 2017. USDA Special Interest Database on Flavonoids. Nutrient Data Laboratory, Beltsville Human Nutrition Research Center, Agricultural Research Service (ARS), U.S. Department of Agriculture (USDA), https:// doi.org/10.15482/USDA.ADC/1178142

Cheema M.A., Qureshi M.A., Havenstein G.B., 2003. A comparison of the immune response of a 2001 commercial broiler with a 1957 randombred broiler strain when fed representative 1957 and 2001 broiler diets. Poult. Sci. 82, 1519-1529, https://doi. org/10.1093/ps/82.10.1519

Choct M., 2015. Feed non-starch polysaccharides for monogastric animals: classification and function. Anim. Prod. Sci. 55, 13601366, https://doi.org/10.1071/AN15276

Cowieson A.J., Lu H., Ajuwon K.M., Knap I., Adeola O., 2016. Interactive effects of dietary protein source and exogenous protease on growth performance, immune competence and jejunal health of broiler chickens. Anim. Prod. Sci. 57, 252-261, https://doi. org/10.1071/AN15523

Ebling P.D., Kessler A.M., Villanueva A.P., Pontalti G.C., Farina G., Ribeiro A.M.L., 2015. Rice and soy protein isolate in prestarter diets for broilers. Poult. Sci. 94, 2744-2752, https://doi. org/10.3382/ps/pev279

Ford J.T., Wong C.W., Colditz I.G., 2001. Effects of dietary protein types on immune responses and levels of infection with Eimeria vermiformis in mice. Immunol. Cell Biol. 79, 23-28, https://doi. org/10.1046/j.1440-1711.2001.00788.x

Friedman M., Brandon D.L., Bates A.H., Hymowitz T., 1991. Comparison of a commercial soybean cultivar and an isoline lacking the Kunitz trypsin inhibitor: composition, nutritional value, and effects of heating. J. Agric. Food Chem. 39, 327-335, https://doi. org/10.1021/jf00002a022

Grieshop C.M., Fahey G.C. Jr, 2000. The role of soy in companion animal nutrition. In: J.K. Drackley (Editor). Soy in Animal Nutrition. Federation of Animal Science Societies. Savoy, IL (USA), pp. 171-181
Irish G.G., Balnave D., 1993. Non-starch polysaccharides and broiler performance on diets containing soyabean meal as the sole protein concentrate. Aust. J. Agric. Res. 44, 1483-1499, https://doi.org/10.1071/AR9931483

Jankowski J., Juskiewicz J., Gulewicz K., Lecewicz A., Slominski B.A., Zdunczyk Z., 2009. The effect of diets containing soybean meal, soybean protein concentrate, and soybean protein isolate of different oligosaccharide content on growth performance and gut function of young turkeys. Poult. Sci. 88, 2132-2140, https://doi.org/10.3382/ps.2009-00066

Jin S.-H., Corless A., Sell J.L., 1998. Digestive system development in post-hatch poultry. Worlds Poult. Sci. J. 54, 335-345, https://doi.org/10.1079/WPS19980023

Li Z., Li D., Qiao S., Zhu X., Huang C., 2003. Anti-nutritional effects of a moderate dose of soybean agglutinin in the rat. Arch. Anim. Nutr. 57, 267-277, https://doi.org/10.1080/00039420 310001594414

Longo F.A., Menten J.F.M., Pedroso A.A., Figueiredo A.N., Racanicci A.M.C., Gaiotto J.B., Sorbara J.O.B., 2005. Different sources of protein in the diet of newly hatched chicks. Rev. Bras. Zootecn. 34, 112-122, https://doi.org/10.1590/S151635982005000100015

Lozovaya V.V., Lygin A.V. Zernova O.V., Ulanov A.V., Li S., Hartman G.L., Widholm J.M., 2007. Modification of phenolic metabolism in soybean hairy roots through down regulation of chalcone synthase or isoflavone synthase. Planta 225, 665-679, https://doi.org/10.1007/s00425-006-0368-z

Mierziak J., Kostyn K., Kulma A., 2014. Flavonoids as important molecules of plant interactions with the environment. Molecules 19, 16240-16265, https://doi.org/10.3390/molecules 191016240

Noy Y., Sklan D., 1997. Posthatch development in poultry. J. Appl. Poult. Res. 6, 344-354, https://doi.org/10.1093/japr/6.3.344

Peisker M., 2001. Manufacturing of soy protein concentrate for animal nutrition. In: J. Brufau (Editor). Feed Manufacturing in the Mediterranean Region. Improving Safety: From Feed to Food. International Center for Advanced Mediterranean Agronomic Studies (CIHEAM). Zaragoza (Spain), pp. 103-107

Saki A.A., Abbasinezhad M., Ghazi Sh., Tabatabai M.M., Ahmadi A., Zaboli Kh., 2012. Intestinal characteristics, alkaline phosphatase and broilers performance in response to extracted and mechanical soybean meal replaced by fish meal. J. Agric. Sci. Technol. 14, 105-114

Siddhuraju P., Becker K., 2005. Nutritional and antinutritional composition, in vitro amino acid availability, starch digestibility and predicted glycemic index of differentially processed mucuna beans (Mucuna pruriens var. utilis): an under-utilized legume. Food Chem. 91, 275-286, https://doi.org/10.1016/j. foodchem.2004.02.044

Sklan D., Noy Y., 2003. Crude protein and essential amino acid requirements in chicks during the first week posthatch. Br. Poult. Sci. 44, 266-274, https://doi.org/10.1080/0007166031000124586

van der Eijk C., 2015. Reducing anti-nutritional factors in prestarter feeds. Asian Feed Mag. March/April, 6-9

Wijtten P.J.A., 2011. Nutrition driven small-intestinal development and performance of weaned pigs and young broilers (PhD Thesis). Wageningen University. Wageningen (The Netherlands)

Willemsen H., Everaert N., Witters A., De Smit L., Debonne M., Verschuere F., Garain P., Berckmans D., Decuypere E., Bruggeman V., 2008. Critical assessment of chick quality measurements as an indicator of posthatch performance. Poult. Sci. 87, 2358-2366, https://doi.org/10.3382/ps.2008-00095 